\title{
Improving the Students' Speaking Ability of Report Text through Stop Motion Video Technique in Junior High School
}

\author{
Fikry Aji Wicaksono \\ MTs Unggulan Al-Jadid, email: fikryajiw@gmail.com \\ Isma Hidayati \\ SMK IKIP Gedangan Sidoarjo, email: ismahidayati27@gmail.com \\ Widya Eka Septiani \\ STKIP PGRI Sidoarjo, email: widyaekaseptiani97@gmail.com
}

\begin{abstract}
This research was Classroom Action Research. This research aimed at implementing stop motion video technique to improve students speaking ability of report text in junior high school and the students' perception in implementation of stop motion video technique to improve the students' speaking ability of report text. The subject of this research was the second grade of junior high school. The focus of this research was the students' speking ability. The data were in the form of students' speaking score. The data were obtained through conducting teaching learning process. The result of this research was that there were improvement in students' speaking ability through Stop Motion Video technique in whole skills. The improvement was up to 40\%-90\%. They were pronunciation, grammar, vocabulary, fluency, and understanding. The students' perception showed that all of the students were motivated after conducted this learning technique. This was showed by the questionnaires filled by the students.
\end{abstract}

Keywords: students' speaking ability, report text, stop motion video technique

\section{INTRODUCTION}

Language is a tool for humans to communicate with one another; through language, people can express their thoughts, feelings, and ideas. According to Wardhaugh (1977, p.3), language is a system of arbitrary vocal symbols that are used to communicate with other humans. People can communicate more easily in social situations when they speak a common language. There are many languages that are used for communication around the world, but only one language that is used as an international language, and that language is called English. According to Crystal (1997), the number of people in the world who communicate in English with international speakers is steadily increasing when compared to the number of people who communicate in other languages. English is a foreign language in Indonesia, and it is spoken by many people. Education in English is provided in both formal and informal settings. Since the beginning of elementary school, students are required to take an English 
course. Furthermore, they are required to take this subject in both junior and senior high school as a compulsory subject.

The ability to communicate effectively in English has become increasingly important for people all over the world in this twenty-first century. This is due to the fact that, first, English has surpassed all other languages as the primary language of global communication, and second, almost all information is written and delivered in English. This statement is supported by the fact that approximately 380 million people speak English as an international language, demonstrating that English is now widely spoken throughout the world. English is also used by over one billion people who speak English as a second (or additional) language to communicate with other second language users from all over the world, regardless of their cultural and linguistic backgrounds or differences (Crystal, 1997). For example, information shared through social media, which anyone from anywhere in the world can access with relative ease, is particularly valuable. As a result, mastery of the English language appears to be a requirement, particularly in public speaking. Speaking employs a communicative approach, which is used in some activities to allow students to practice English in a communicative manner (Sulistyaningsih, 2016).

Unfortunately, the fact shows that many students are still incapable in mastering English. For in school, they learn not only about speaking skill, but also listening, reading, and writing skills. This is in line with (Hamsia, 2018) which states in her journal that the students are expected to master those four language skills. The skill seems intuitively the most important one. This condition makes the students' concentration disorganized like unconfident and get less motivated to speak in front of the class. They are forced to be master in many subjects in a same time when they are learning in the classroom.

In junior high schools, speaking is one of the four English skills that must be learnt by the students. For English is as foreign language for Indonesian students, which they do not apply in their daily communication, teaching speaking English is not easy. (Linse, 2005) states that to be able in speaking English well, they need to study the other sub-skills such as pronunciation, vocabulary, and grammar. Beside, students' self-confident in practicing English is also cannot be improve because their mind will be tampered with some concept from structure, grammar, and so on. In addition, (Thornbury \& Slade, 2006) state that speaking is also a multi-sensory activity because it involves paralinguistic features such as eye-contact, facial expressions, body language, tempo, pauses, voice quality changes, and pitch variation which affect conversational flow. To overcome this case, the teacher should 
be capable in teaching, especially in teaching English. From the teacher's point of view, the success of speaking learning and teaching process depends on his/her ability in speaking English such as the mastery of pronunciation, grammar, vocabulary, and also his/her competence in using target language to communicate.

In fact, students' speaking right now is low because lack of self-confidence. On the other hand, they are expected to master four skills in the same time. (Richards \& Renandya, 2002) state that a possible way of stimulating students to talk might be done by providing them with the extensive exposure to authentic language through audio-visual stimuli and with opportunities to use the language. Understanding this condition, the researchers intend to conduct this research to improve the students' speaking ability. So that the students can apply their ability in speaking as the main function of learning language, that is to communicate. In this case, the research is about improving the students' speaking ability of report text through stop motion video technique in junior high school. The researchers decide to improve students' speaking because speaking is the evidence whether the students mastering language or not.

Speaking is more about the process rather than just a product. There are several reasons to use a video in teaching speaking. First, video includes audio-visuals which are interesting for students. Second, it gives an authentic material with the right pronunciation and vocabulary for students to practice. And third, video shows the right situation of the conversation and the right body language of the speaker to the audience. Besides, video also improves students' cultural understanding of English. The use of video in students' speaking activity is helpful to stimulate and motivate them to speak. It is believed that the use of video activity in the students' speaking class will give a positive contribution to their speaking skill. That is why the researchers choose video as an alternative way to help students improve their speaking skill. In line with this, the researchers decide to use stop motion video as a technique and video itself as a media to find out whether or not this technique can solve the problem.

The researchers choose junior high school students because this grade is suitable to practice their English after getting basic material from elementary school. In addition, this eighth grade junior high school also discuss about report text material where it is a better time to apply their speaking. (Tristy, 2010) says that report gives information about a subject which is being the topic of the text. But in this research, the students will give 
information based on the video that is stopped by the teacher. So, it is appropriate to conduct this research about improving students' speaking ability through stop motion video technique.

In conducting this research, the researchers state the statements of the problem. The first is how is the implementation of stop motion video technique to improve students speaking ability of report text in junior high school, and the second is how are the students' perception in implementing stop motion video technique to improve the students' speaking ability of report text.

As like the statement of the problem that are consist of two points, the researchers also explain two points of the objective of the study. They are to describe the implementation of stop motion video technique to improve students speaking ability of report text in junior high school and to describe the students' perception in implementation stop motion video technique to improve the students' speaking ability of report text. According to 2013 curriculum, one of the texts that are learned by junior high school students is report text (Derewianka, 1990) state that report text is a text that has purpose to describe the way things are, with reference to a range of natural, man-made and social phenomena in our environment. Says that information reports classify and describe the phenomena of ourworld. We use them when we talk about a whole class of things, like bikes. The major focus of this text is on "thing" (or more accurately, a class of thing) rather than a sequence. The topic of the report is usually introduction by an opening general statement or general classification and followed by a series of description paragraphs about the topic.

Related to the objectives of the study, this research has significances of the study. The researchers describe four significances of the study. The first, for the teacher, this research will facilitate the teacher in teaching speaking through different and convenient way which is not make the students bored. The second, for the students, the students will be able to practice their speaking ability through convenient way which they can face in daily life. The third, for the reader, the researchers intended to give beneficial information to the reader related to teaching speaking through stop movie media for junior high school students. And the forth, for the researcher, this research will give the researcher sufficient information about improving the students' speaking ability in report text material through stop movie media in junior high school students.

Furthermore, the researchers have two previous of the study. The first is conducted by Itsna Millatul Himmayati from IAIN Salatiga. The title of her research is "The Use of 
Retelling Short Movie Technique to Improve the Students' Speaking Mastery (A Classroom Action Research at the First Grade of MAN Tengaran in the Academic Year 2016/2017)". Classroom action research is the methodology of this research. The second researcher is from Yogyakarta State University. The researcher is Arum Mustikawati. The title of the research is "The Effectiveness of using Video in Teaching Speaking for the Eight Grade Students of SMPN 1 Manisrenggo". This research was classified as a quasi-experimental study. Those researches have another similarities and differences. The researchers have found the similarities and the differences of her research and those two researches. The similarities of the first previous of the study and this research is improving students' speaking skill. Meanwhile, the differences are this research subject is junior high school students, while the first previous of the study was senior high school student. In addition, the research design of this research is descriptive qualitative research, while the first previous was classroom action research. Meanwhile, the difference is this research using descriptive qualitative research as the research subject, while the second previous using quasy-experimental study. The result of first previous the study showed that the students' speaking skill was improved after using retelling short movie, picture and discussion in teaching learning process. While the result of second previous the study showed that the video technique significantly improves the students' speaking ability.

\section{METHOD}

This research was conducted in second grade students of MTs Unggulan Al-Jadid. There were ten students that became the subject of this research. The focus of this research was the students' speaking ability. Four steps were done to conduct this research. They were planning, action, observation and reflection. In this study, Classroom Action Research (CAR) was chosen by the researchers. For the aimed of this research was to improve students' speaking ability of report text through stop motion video technique, so this research was appropriate used Classroom Action Research. The research was done twice in cycle 1 and cycle 2 . The result of cycle 1 and cycle 2 would be different. The researchers would describe the process of how the stop motion video technique could improve students' speaking ability. Instruments used in this research were observation field note, video, speaking's table score, and questionnaire. By these instruments, the data gotten would be more legitimate and it could answer the statements of the problem easily. 
Before the technique was implemented, the students had gotten the report text material. The researcher began with explaining the instruction how the class would be run. The researcher played the video and the students should pay attention on it. Then, the video would be stopped by the researcher in random time. One of the student should tell what has happened, seems like he or she report a news or an event. After that, the video was continued and another student would do the same. This research was conducted twice in the different day. By conducting this research, it would be appeared the differences of the students' speaking ability between in cycle 1 and cycle 2 .

Research design used in this study was the design of Classroom Action Research (CAR). This design was a spiral model of learning. According to (Kemmis, McTaggart, \& Nixon, 2014), CAR consisted of 4 (four) stages, the first cycle moved through the major steps of planning, action, observation and reflection, which were then used to revise the process in the next cycle. Those were the feature and explanation about the cycles by this following:

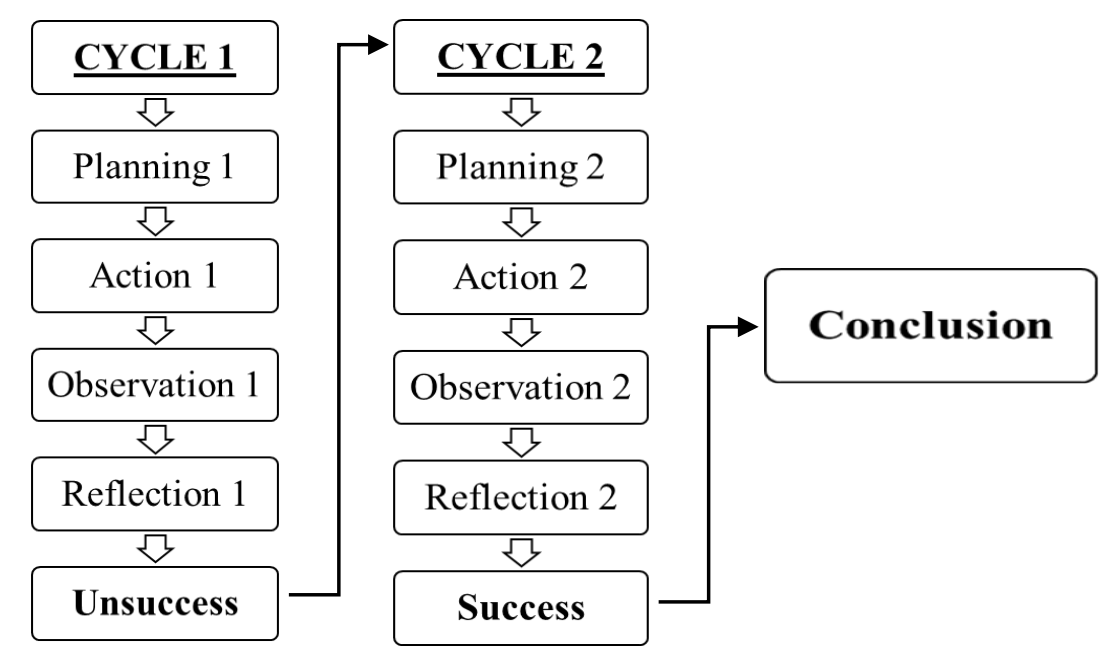

Figure 1. Classroom Action Research

\section{Planning stage}

The planning stage was the preparation of an action to perform researchers to carry out the next stage or action stage. The planning phase included researcher prepared all purposes of Classroom. Action Research, materials, methods of teaching, creates action steps for the implementation of the action stage, observation preparation and evaluation.

Preparation of research instruments included video about report text for students and for observer, observation sheet, and assessment sheet, speaking rubric.

\section{Action stage}

In this action stage researchers implemented the steps that have been set in the planning 
stage. In this stage, researchers would play a video, stop the video randomly, then the students had to report the event of the video they had watched until the video was stopped. Rubric of speaking used to observing student's ability in speaking skill.

\section{Observing stage}

Observing stage was conducted by the researchers, observations was made in order to obtain a record of all the events that occur during the practice of speaking report text by observing and recording the observation sheet or assessment sheet and based on the rubric. Then, researcher conducted the assessment after the implementation process; the assessment was accordance with the instructions on the observation sheet.

\section{Reflecting stage}

Researchers conducted an intense reflection about the results of the action stage and observing stage. Researchers analysed data obtained systematically, and made repairing if there was a shortage so that the next cycle could be better.

\section{Data Collection Procedure}

Data collection procedure was conducted steps by steps. The researchers collected the data during the research. Then, researchers analysed the data and reflection note. The data were in scoring form. The score were calculated and compared between the score in cycle 1 and cycle 2. The main purpose of this study was to obtain precise and valid data in accordance with the title of research. So the data collection procedures was strategic step in the research. Without knowing the procedures of data collection, the researcher would not get the data that set of data standards.

\section{Observation Field Note}

Observation field note was a way of observation and record direct and systematic review of the learning process in the classroom. Researcher looked at the practice of stop motion video technique to improve students' speaking ability of report text which takes place directly. Then researcher recorded any events or facts that occurred during the last practice, to obtain the required data in the study. The researcher could get the studentse development in pronunciation.

\section{Questionnaire}

The researchers gave the questionnaire to the students after implemented the teaching technique. There were three kinds of questionnaire. They were about speaking, stop motion 
video, and report text which each questionnaire consisted of five questions. This was conducted to know the students' perception about speaking skill and the learning process conducted in advance.

\section{Documentation}

Documentation was how the researcher found out the data written text data, such as, internet, magazine, document record, or from books. With this way researcher find out the data from document record of the school. The document record was likes school system, work mechanism, written text, the schools' role, and picture and video recorded. Then, researcher selected the document according to the research focus.

\section{Data Analysis}

From information that researcher gets above, researcher explained the data analysis technique. Those were:

\section{Data from observation assessment}

From the result of observations, the researcher explains the use of stop motion video technique to improve students' speaking ability of report text in mastering speaking skill. The data of speaking report text are obtained from the observation checklist. Rubric assessment of speaking will be used to know the students speaking's scores.

Table 1. Description of Speaking Skills' Score

\begin{tabular}{|c|c|c|}
\hline $\begin{array}{c}\text { SKILL } \\
\text { OF SPEAKING }\end{array}$ & SCORE & DESCRIPTION \\
\hline \multirow{5}{*}{ Pronunciation } & 1 & Serious pronunciation problems that cannot be understood \\
\hline & 2 & $\begin{array}{l}\text { Difficult to understand due to pronunciation problems, often } \\
\text { asked to repeat }\end{array}$ \\
\hline & 3 & $\begin{array}{l}\text { There are pronunciation problems that require the listener to be } \\
\text { fully concentrated and sometimes there are misunderstandings }\end{array}$ \\
\hline & 4 & Easy to understand even with a certain accent \\
\hline & 5 & Easy to understand and has a native speaker's accent \\
\hline \multirow{5}{*}{ Grammar } & 1 & $\begin{array}{l}\text { The grammar mistakes are so severe that they are difficult to } \\
\text { understand }\end{array}$ \\
\hline & 2 & $\begin{array}{l}\text { Lots of grammar mistakes that obstruct the meaning and often } \\
\text { rearrange sentences }\end{array}$ \\
\hline & 3 & Often makes grammatical mistakes that affect meaning \\
\hline & 4 & $\begin{array}{l}\text { Sometimes makes grammatical errors but doesn't affect the } \\
\text { meaning }\end{array}$ \\
\hline & 5 & No or few grammatical errors \\
\hline \multirow{4}{*}{ Vocabulary } & 1 & Vocabulary is so limited that conversation is impossible \\
\hline & 2 & $\begin{array}{l}\text { Using vocabulary incorrectly and limited vocabulary making it } \\
\text { difficult to understand }\end{array}$ \\
\hline & 3 & $\begin{array}{l}\text { Frequent use of inappropriate vocabulary, limited conversation } \\
\text { due to vocabulary limitations }\end{array}$ \\
\hline & 4 & Sometimes uses inappropriate vocabulary \\
\hline
\end{tabular}




\begin{tabular}{|l|c|l|}
\hline & $\mathbf{5}$ & Use vocabulary and expressions like a native speaker \\
\hline \multirow{4}{*}{ Fluency } & $\mathbf{1}$ & Talking stutters and stops making conversation impossible \\
\cline { 2 - 3 } & $\mathbf{2}$ & Often hesitates and pauses due to language limitations \\
\cline { 2 - 3 } & $\mathbf{3}$ & Fluency is somewhat impaired by language problems \\
\cline { 2 - 3 } & $\mathbf{4}$ & Fluency seems a bit compromised by language problems \\
\cline { 2 - 3 } & $\mathbf{5}$ & Fluent like a native speaker \\
\cline { 2 - 3 } & $\mathbf{1}$ & Cannot understand even a simple conversation \\
\cline { 2 - 3 } & $\mathbf{2}$ & Difficulty following what is being said. \\
\cline { 2 - 3 } & $\mathbf{3}$ & $\begin{array}{l}\text { Understands most of what is said when speech is slowed down } \\
\text { a bit despite repetition }\end{array}$ \\
\cline { 2 - 3 } & $\mathbf{4}$ & $\begin{array}{l}\text { Understands almost everything, although there are repetitions in } \\
\text { certain parts }\end{array}$ \\
\cline { 2 - 3 } & $\mathbf{5}$ & Understand all without difficulty \\
\hline
\end{tabular}

That table of the description was taken from (Hanik, 2011). There were five of speaking skills. They were pronunciation, grammar, vocabulary, fluency, and understanding. The classification of the score was 1 is the lowest and 5 is the highest. After getting result score from percentage calculation researchers could conclude whether there was improvement or not in students' speaking ability by compared the score in cycle 1 and cycle 2 .

Meanwhile, to get the students' perception, the researcher used the table from (Augustin, 2017). This was the following tables. From this table, it could be concluded how was the students' perception of speaking ability, stop motion video, and report text. This questionnaire was intended to investigate the students' perception during followed the learning process.

Table 2. Table of Speaking Questionnaire

\begin{tabular}{|c|l|c|c|c|c|}
\hline No. & \multicolumn{1}{|c|}{ Statement } & SA & A & D & SD \\
\hline 1. & I am nervous when talking. & & & & \\
\hline 2. & I am unfamiliar with what to say. & & & & \\
\hline 3. & $\begin{array}{l}\text { I am more willing to respond in class if I prepare } \\
\text { in advance. }\end{array}$ & & & \\
\hline $\begin{array}{l}\text { I feel more comfortable answering the teacher's } \\
\text { questions when I do not have to do it in front of } \\
\text { the whole class. }\end{array}$ & & & & \\
\hline 5. & $\begin{array}{l}\text { My classmates in this class do not respect each } \\
\text { other's views. }\end{array}$ & & & \\
\hline
\end{tabular}

Table 3. Table of Stop Motion Video Questionnaire

\begin{tabular}{|c|l|c|c|c|c|}
\hline No. & \multicolumn{1}{|c|}{ Statement } & SA & A & D & SD \\
\hline 1. & Stop motion Video is the good video animation & & & & \\
\hline 2. & I am very happy to report when the video stop & & & & \\
\hline 3. & $\begin{array}{l}\text { I want to learn more about stop motion video } \\
\text { with expression }\end{array}$ & & & & \\
\hline 4. & I am very surprise when I try to answer when the & & & & \\
\hline
\end{tabular}




\begin{tabular}{|c|l|l|l|l|l|}
\hline & video stop & & & & \\
\hline 5. & $\begin{array}{l}\text { I can write and speaking to describe what happen } \\
\text { in the video with my opinion }\end{array}$ & & & & \\
\hline
\end{tabular}

Table 5. Table of Report Text Questionnaire

\begin{tabular}{|c|l|c|c|c|c|}
\hline No. & \multicolumn{1}{|c|}{ Statement } & SA & A & D & SD \\
\hline 1. & I can get the information from report text & & & & \\
\hline 2. & $\begin{array}{l}\text { I can report the definition and purpose language } \\
\text { in report text }\end{array}$ & & & & \\
\hline 3. & Ican study more about report text & & & & \\
\hline 4. & I know the fact and imagine something happen & & & & \\
\hline 5. & $\begin{array}{l}\text { I can use the simple present tense to make the } \\
\text { structure in report text }\end{array}$ & & & & \\
\hline
\end{tabular}

SA $=$ Strongly Agree

$\mathrm{A} \quad=$ Agree

$\mathrm{D} \quad=$ Disagree

$\mathrm{SD} \quad=$ Strongly Disagree

\section{RESULT AND DISCUSSION}

(Kemmis, McTaggart, \& Nixon, 2014) exposed that CAR consisted of four stages, they were planning, action, observation and reflection. The planning of this research had already prepared well by the researcher. Start from choosing the appropriate school, grade, material, and also the video that were used to conduct this research. Moreover, the researcher did the action in the class chosen while observed the learning process by using technique of this research. Field note was used in this process. Furthermore, the researcher did the reflection after conducted this research.

This part aims at discussing the result of the research based on the result improving the students' speaking ability of report text through stop motion video technique in junior high school. The researchers divided the result based on the statements of the problem. They are how the implementation of stop motion video technique is to improve students speaking ability of report text in junior high school and how the students' perception are in implementation of stop motion video technique to improve the students' speaking ability of report text.

\section{The implementation of stop motion video technique to improve students speaking ability of report text in junior high school}

In this research, there were ten students as the subject. Meanwhile, the object of this research were the students' speaking ability. The application of stop motion video technique 
in learning narrative material in eighth grade of junior high school was conducted to improve the students' speaking ability. There were five main skills of speaking that would be the reference for taking the score in implementing this research. They were pronunciation, grammar, vocabulary, fluency and understanding. Before implementing this technique, the students had already gotten the material about narrative. The treatment was conducted twice. This following table showed the result of the first cycle.

Table 4. Students speaking's Scores in Cycle 1

\begin{tabular}{|c|l|c|c|c|c|c|}
\hline \multirow{2}{*}{ NO } & \multirow{2}{*}{ NAME } & \multicolumn{5}{|c|}{ SCORE } \\
\cline { 3 - 7 } & & Pronunciation & Grammar & Vocabulary & Fluency & Understanding \\
\hline 1 & Muhammad S. A & 3 & 4 & 4 & 2 & 3 \\
\hline 2 & Pradina R. & 3 & 3 & 3 & 2 & 4 \\
\hline 3 & Ade A. & 3 & 2 & 2 & 2 & 2 \\
\hline 4 & Amelia C. P. & 3 & 2 & 2 & 3 & 3 \\
\hline 5 & Siti S. & 3 & 3 & 2 & 4 & 4 \\
\hline 6 & Lellyta S. S. & 3 & 2 & 2 & 1 & 3 \\
\hline 7 & Arta M. J. & 3 & 4 & 4 & 1 & 2 \\
\hline 8 & Earta P. & 4 & 3 & 3 & 3 & 2 \\
\hline 9 & Firda A. & 4 & 3 & 3 & 1 & 3 \\
\hline 10 & Vika A. & 3 & 4 & 4 & 2 & 4 \\
\hline
\end{tabular}

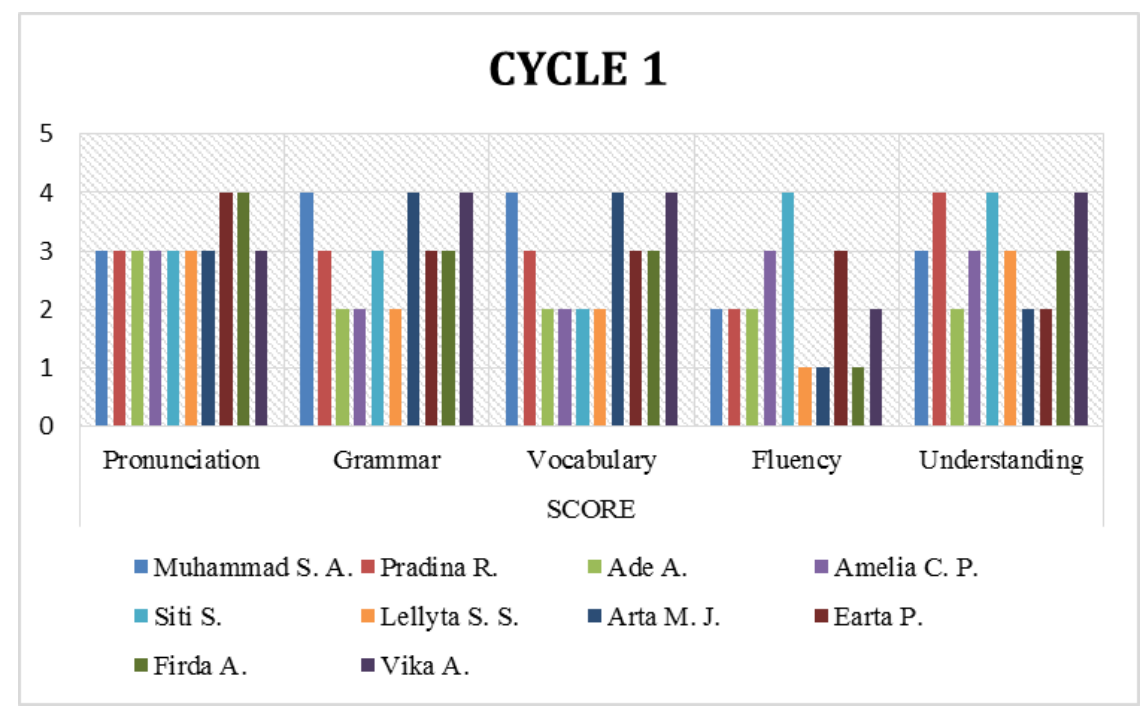

Figure 2. Score in Cycle 1

The table 4. showed that there were ten students as the subject of this research. In pronunciation, among ten students, only two of them who got the score 4, while the rest only got 3. In grammar, the scores were more various, three students got score 4 , four students got 3 , and three students got 2 . In vocabulary, three students got 4 , three students got 3 , and four students got 2. In fluency, only one student got 4 , two students got 3 , four students got 2 , and three students got 1. Moreover, in understanding, there were three students got 4, four 
Improving the Students' Speaking Ability of Report Text through Stop Motion Video Technique in Junior High School

students got 3, and three students got 2 .

From the table, it was known that there were no students got 5 for the score, while only few numbers of the students got 1 for the score that was in fluency skill. Furthermore, this following table was the result of the second cycle.

Table 5. Students speaking's Scores in Cycle 2

\begin{tabular}{|c|l|c|c|c|c|c|}
\hline \multirow{2}{*}{ NO } & \multirow{2}{*}{ NAME } & \multicolumn{5}{|c|}{ SCORE } \\
\cline { 3 - 7 } & & Pronunciation & Grammar & Vocabulary & Fluency & Understanding \\
\hline 1 & Muhammad S. A. & 4 & 4 & 5 & 3 & 4 \\
\hline 2 & Pradina R. & 3 & 5 & 3 & 3 & 4 \\
\hline 3 & Ade A. & 3 & 4 & 2 & 3 & 4 \\
\hline 4 & Amelia C. P. & 3 & 4 & 3 & 3 & 4 \\
\hline 5 & Siti S. & 5 & 3 & 3 & 4 & 4 \\
\hline 6 & Lellyta S. S. & 3 & 3 & 2 & 3 & 3 \\
\hline 7 & Arta M. J. & 3 & 4 & 5 & 2 & 3 \\
\hline 8 & Earta P. & 5 & 3 & 3 & 4 & 3 \\
\hline 9 & Firda A. & 4 & 3 & 4 & 3 & 4 \\
\hline 10 & Vika A. & 3 & 5 & 5 & 2 & 4 \\
\hline
\end{tabular}

In the table above, the number of the students were, that were ten. In addition, the speaking skills were also same. There were pronunciation, grammar, vocabulary, fluency, and understanding. In pronunciation, there were two students got 5, two students got 4 , and six students got 3. In grammar, there were two students got 5, four students got 4, and four students got 3 . In vocabulary, there were three students got 5 , one student got 4 , four students got 3, and two students got 2. In fluency, there were two students got 4, six students got 3, and two students got 2. Moreover, in understanding, there were seven students got 4 and three students got 3 .

Table 6. Students' Average Speaking Scores

\begin{tabular}{|c|l|c|c|c|}
\hline \multirow{2}{*}{ NO } & \multirow{2}{*}{ NAME } & \multicolumn{2}{|c|}{ AVERAGE } & IMPROVEMENT \\
\cline { 3 - 5 } & & CYCLE 1 & CYCLE 2 & PERENTAGE \\
\hline 1 & Muhammad S. A. & 3.2 & 4 & $80 \%$ \\
\hline 2 & Pradina R. & 3 & 3.6 & $60 \%$ \\
\hline 3 & Ade A. & 2.2 & 3.2 & $100 \%$ \\
\hline 4 & Amelia C. P. & 2.6 & 3.4 & $80 \%$ \\
\hline 5 & Siti S. & 3.2 & 3.8 & $60 \%$ \\
\hline 6 & Lellyta S. S. & 2.2 & 2.8 & $60 \%$ \\
\hline 7 & Arta M. J. & 2.8 & 3.4 & $60 \%$ \\
\hline 8 & Earta P. & 3 & 3.6 & $60 \%$ \\
\hline 9 & Firda A. & 2.8 & 3.6 & $80 \%$ \\
\hline 10 & Vika A. & 3.4 & 3.8 & $40 \%$ \\
\hline
\end{tabular}




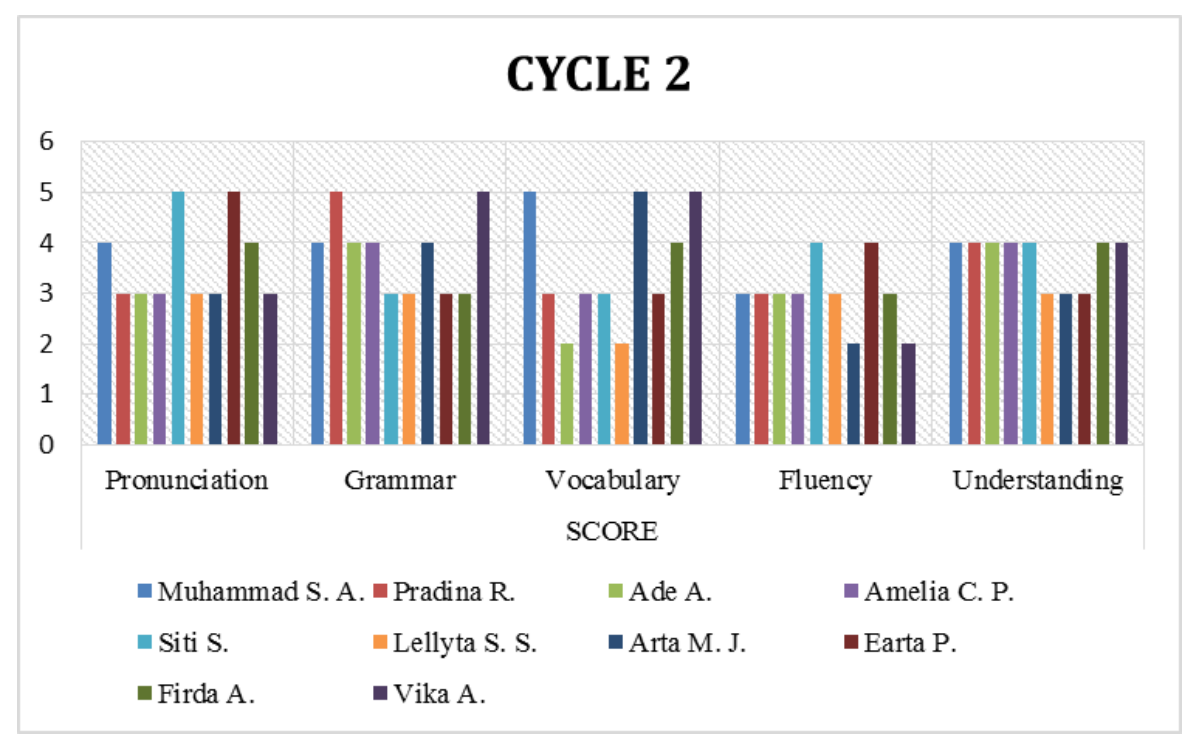

Figure 3. The Score in Cycle 2

The table above showed the average between the cycle 1 and cycle two based on the students' point of view. The data showed that each of the students' speaking skills was improved by conducting the technique if this research. It meant that this research was succeed. The percentage of the students' speaking improvement was also displayed into this diagram.

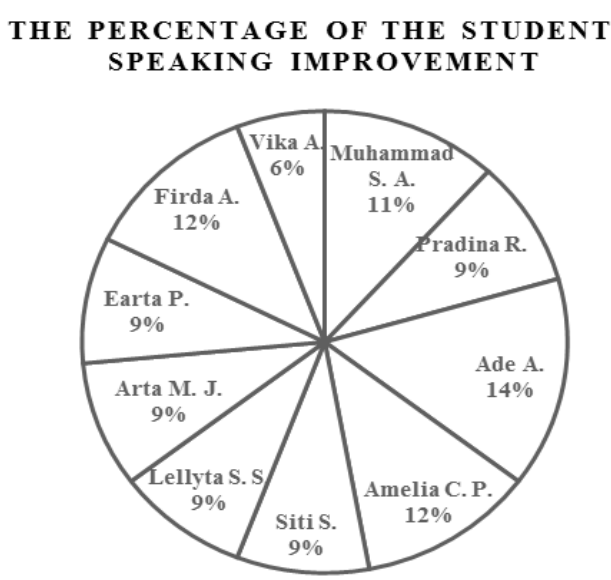

Moreover, the average of the students' speaking score based on the speaking skills displayd into a table and diagram.

Table 9. Speaking Skills' Average Scores

\begin{tabular}{|l|c|c|c|}
\hline & CYCLE 1 & CYCLE 2 & $\begin{array}{c}\text { IMPROVEMENT } \\
\text { PERENTAGE }\end{array}$ \\
\hline Pronunciation & 3.2 & 3.6 & $40 \%$ \\
\hline Grammar & 3 & 3.8 & $80 \%$ \\
\hline Vocabulary & 2.9 & 3.5 & $60 \%$ \\
\hline Fluency & 2.1 & 3 & $90 \%$ \\
\hline Understanding & 3 & 3.7 & $70 \%$ \\
\hline
\end{tabular}


In line with the previous table, the table above also showed the average of students speaking's score, yet this table was based on the speaking skills. There were pronunciation, grammar, vocabulary, fluency, and understanding. Moreover, all of the speaking skills were improved by conducting the technique of this research.

THE PERCENTAGE OF SPEAKING SKILLS

SCORE IMPROVEMENT

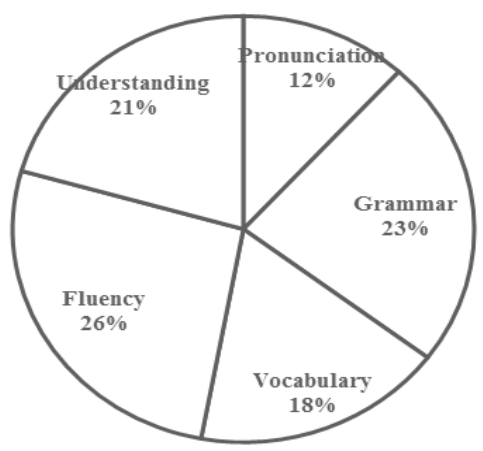

The students' perception in implementation stop motion video technique to improve the students' speaking ability of report text.

This following questionnaire was taken after conducted the research. This questionnaire was given to the students to get the data about the students' perception during followed the learning process. The first diagram showed the percentage of the speaking questionnaire. There were five statements that were answered by the students whether they agreed or disagreed after implementing stop motion video technique in the classroom.

The first statement was I am nervous when talking. There were $31 \%$ students whom strongly agreed with this statement. The second statement was I am unfamiliar with what to say. There were $15 \%$ students whom strongly agreed with this statement. The third statement was I am more willing to respond in class if I prepare in advance. There were $39 \%$ students whom strongly agreed with this statement. The fourth statement was I feel more comfortable answering the teacher's question when I do not have to do it in front of the whole class. There were $15 \%$ students whom strongly agreed with this statement. The last statement was my classmates in this class do not respect each other's views. There were 0\% students whom strongly agreed with this statement. 


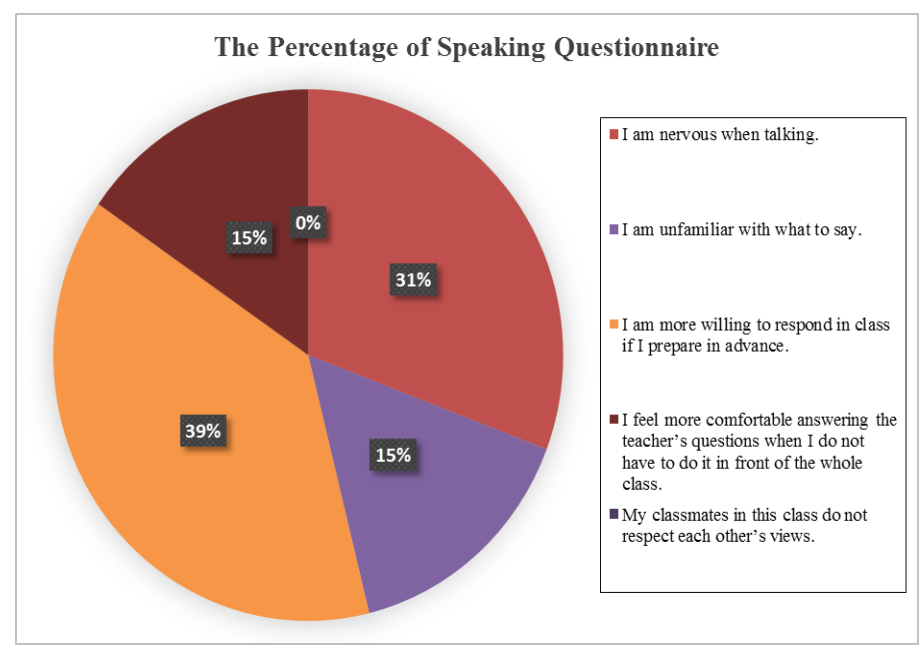

The second diagram was the percentage of stop motion video technique questionnaire. The first statement was stop motion video is the good video animation. There were $21 \%$ students whom strongly agreed with this statement. The second statement was I am very happy to respect when the video stop. There were $24 \%$ students whom strongly agreed with this statement. The third statement was I want to learn more about stop motion video with expression. There were $21 \%$ students whom strongly agreed with this statement. The fourth statement was I am very surprise when I try to answer when the video stop. There were $18 \%$ students whom strongly agreed with this statement. The last statement was I can write and speak to describe what happen in the video with my opinion. There were $16 \%$ students whom strongly agreed with this statement.

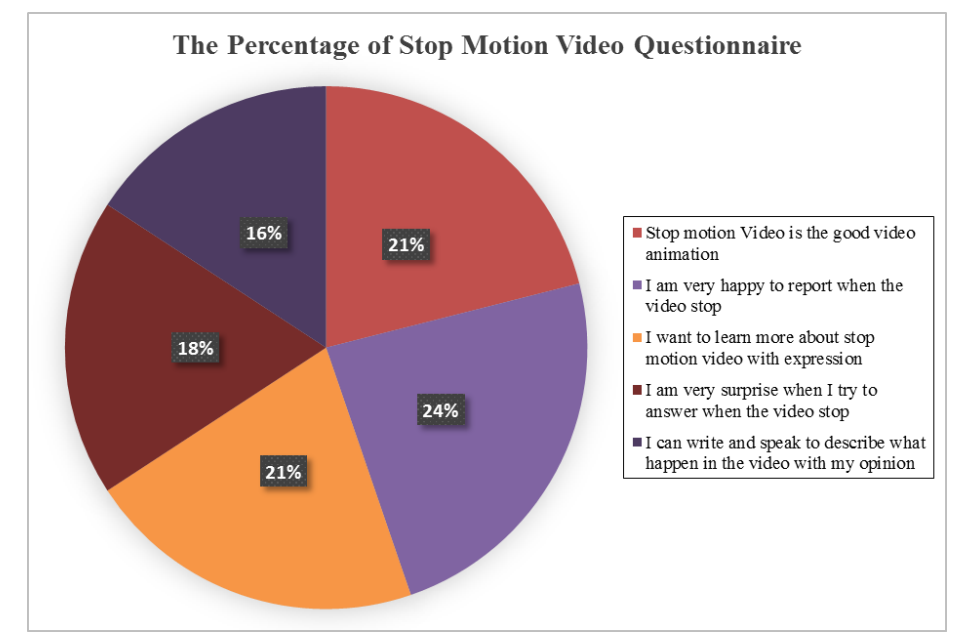

Furthermore, the third diagram was the percentage of report text questionnaire which was filled by the students after implementing stop motion video technique. The first statement was I can get the information from report text. There were $22 \%$ students whom strongly agreed with this statement. The second statement was I can report the definition and 
purpose language in report text. There were $20 \%$ students whom strongly agreed with this statement. The third statement was I want to study more about report text. There were $20 \%$ students whom strongly agreed with this statement. The fourth statement was I know the fact and imagine something happen. There were $15 \%$ students whom strongly agreed with this statement. The last statement was I can use the simple present tense to make the structure in report text. There were $23 \%$ students whom strongly agreed with this statement.

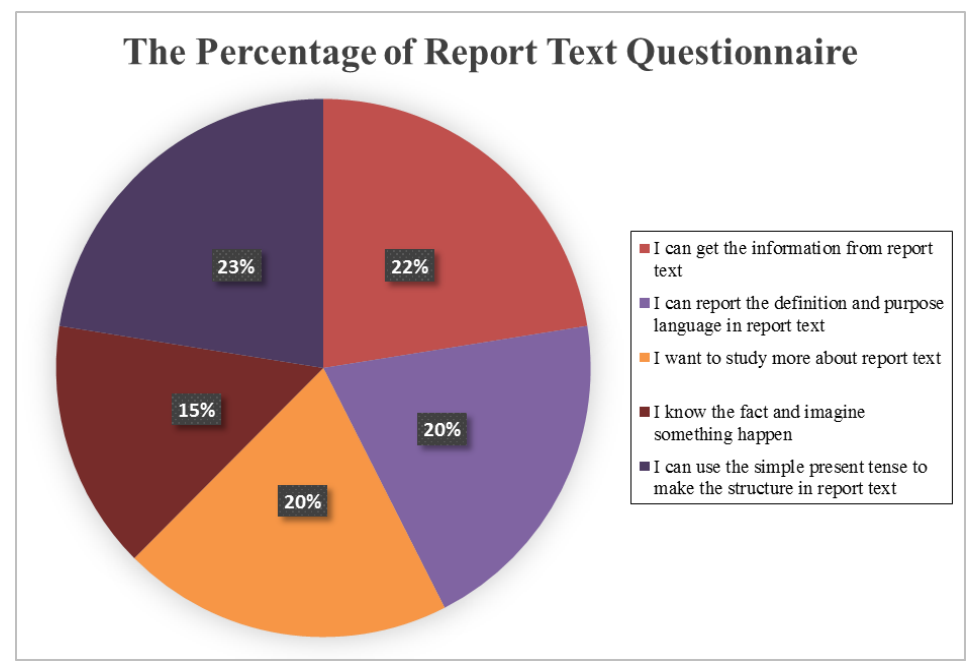

\section{CONCLUSION}

By doing this research, the researchers intended to see whether the implementation of teaching using stop motion video technique could improve students' speaking ability significantly, especially for telling report text. Furthermore, the researcher also tried to know students' perception on the implementation of stop motion video technique in teaching and learning speaking ability of report text. The researchers used (Kemmis, McTaggart, \& Nixon, 2014) about four stages of Classroom Action Research (CAR), including planning, action, observation, and reflection, to make improvement in students' speaking ability in eighth grade of junior high school. As results, the five aspects of speaking skills, which are pronunciation, grammar, vocabulary, fluency, and understanding, were improved. This was evidenced by an increase in the test results of the second cycle compared to the first cycle. The lowest increase occurred in the aspect of pronunciation, while the highest increase was in understanding. Furthermore, the questionnaires filled by the students after implementing stop motion video technique showed that the students expressed a positive attitude towards the application of stop motion video technique in teaching and learning speaking. In other words, the students' perception while applying this technique in their learning process were motivated to improving English speaking ability of report text. The positive impression of the 
Improving the Students' Speaking Ability of Report Text through Stop Motion Video Technique in Junior High School

students is influenced by various factors, the point of which is to make it easier for students to learn and understand the teaching material.

\section{REFERENCES}

Conversation: from description to pedagogy. (2006)CambridgeCambridge University Press

Developing Students' Speaking Ability through Story Completion (2018). Journal of English Language Teaching 57

English as a Global Language. (1997). Cambridge. Cambridge University Press.

Exploring How Text Work (1990) Australia-Sydney

Improving Students' Skill in Writing Report Text with All about Animals VCD2010SemarangSemarang State University Practical English Language Teaching: Young Learners. (2005). New York. McGraw-Hill Companies

Sulistyaningsih. (2016). Games for the Speaking Class. Jurnal Edukasi50 The Action Research Planner. (2014). Singapore. Springer 